\title{
"O lar transformado em inferno": o olhar dos literatos sobre os ressentimentos dentro do casamento
}

\author{
"Home turned into hell": Resentment in marriage in the view of men of letters
}

\author{
Mara Lígia Fernandes Costa $^{1}$ \\ maraufpi@gmail.com
}

\author{
Pedro Vilarinho Castelo Branco ${ }^{2}$ \\ pedrovilarinho@uol.com.br
}

\footnotetext{
' Mestre em História do Brasil (UFPI). Professora do Instituto Camillo Filho. Desenvolve pesquisas nas áreas de História, Família, Gênero e Literatura.

2 Doutor em História pela Universidade Federal de Pernambuco. Professor do Departamento de Geografia e História e do Programa de Pós-Graduação em História do Brasil da Universidade Federal do Piauí, tutor do Programa de Educação Tutorial (PET-História) e líder do Grupo de pesquisa História, Cultura e Gênero do CNPq.
}

Resumo. Os estudos que contemplam uma análise acerca da história das relações amorosas têm oferecido a possibilidade de apreender diferentes visões construídas a respeito das vivências domésticas, especialmente aquilo que está relacionado ao casamento. Nesse sentido, o interesse sobre esta forma de união entre casais a partir do olhar de intelectuais piauienses permitiu perceber a forma como o casamento foi problematizado, revelando concepções que divergiam entre uma concepção romantizada, com a valorização cada vez mais intensa do amor, e ainda uma percepção mais polêmica, envolvendo o debate acerca do divórcio. A proposta deste artigo é analisar como o tema do casamento e da possibilidade de dissolução do matrimônio foi tratado na produção literária durante as primeiras décadas do século XX. O principal objeto de análise centra-se em algumas obras literárias de Clodoaldo Freitas, Abdias Neves, Cândido Gil Castelo Branco, Jônatas Batista e o ensaio jurídico de Luiz de Morais Correia acerca da possibilidade de regulamentação do divórcio na legislação brasileira através de textos que remetiam à valorização do casamento, bem como às ameaças que colocavam em risco a indissolubilidade deste.

Palavras-chave: gênero, família, literatura, divórcio.

Abstract. The studies that analyze the history of love relationships have made it possible to apprehend various views of experiences people have made at home, particularly those related to marriage. Thus, interest in marriage from the point of view of intellectuals of the state of Piauí has shown how that institution became problematic, revealing views that range from a romanticized concept that intensively valued love to a more polemic view involving a debate about divorce. The purpose of this article is to analyze how the topic of marriage and its dissolubility were dealt with by men of letters during the first decades of the 20th century. The main object of analysis are literary works by Clodoaldo Freitas, Abdias Neves, Cândido Gil Castelo Branco, Jônatas Batista and a legal essay by Luiz de Morais Correia on the regulation of divorce in Brazilian legislation through texts that referred to the valuing of marriage as well as to the threats to its indissolubility.

Key words: gender, family, literature, divorce. 
Uma das alterações advindas a partir da incorporação dos valores do mundo moderno é a valorização da cultura letrada, à medida que a escrita foi conquistando um espaço legitimado para determinados grupos da sociedade. Escrever transformou-se em sinal de distinção social, e, segundo esse discurso, o indivíduo, quando inserido no mundo das letras, seria detentor de uma erudição a ser demonstrada na esfera social, principalmente, para a apreciação de seus pares. A intenção dos literatos era que seus escritos promovessem novas ideias que contribuíssem para a construção de uma sociedade adaptada à noção de progresso e civilidade. Mais do que apenas um ato de escrever, esses homens de letras compreendiam a sua função social como transformadora, uma verdadeira “missão social” (Sevcenko, 2003).

É nessa perspectiva que trabalharemos, no presente artigo, com alguns literatos que, no final do século XIX e início do século XX, lançaram mão da escrita para problematizar e definir novos padrões de comportamento familiar, que deveriam ser vivenciados nas práticas cotidianas. Especialmente nas páginas da imprensa piauiense, a produção literária emergiu a partir do esforço de grupos de intelectuais interessados em consolidar o seu papel de orientadores de uma moral social e familiar mais adequada para as necessidades do período em questão. A preferência pela análise da produção intelectual desses homens está relacionada à visibilidade que os mesmos alcançaram dentro da sociedade, motivada pelas suas atividades profissionais - tais como bacharéis, professores e funcionários públicos - recorrentemente associadas com a prática da escrita registrada em periódicos locais e que, por sua vez, impulsionava na devida proporção seus respectivos nomes no círculo intelectual em que estavam inseridos. Tomaremos como objeto de análise obras ficcionais de Clodoaldo Freitas, como Memórias de um velho, $O$ divórcio e Um segredo de família, além de alguns artigos de Abdias Neves, de Cândido Gil Castelo Branco, Jônatas Batista e, finalmente, um ensaio jurídico, de Luiz de Morais Correia.

Os documentos selecionados nos mostram que $o$ espaço do lar, da família, diferentemente dos padrões idealizados, muitas vezes, era caracterizado por ressentimentos. A desarmonia protagonizada pelos cônjuges emerge, então, como tema a ser discutido pelos literatos. Assim, a escrita desses intelectuais buscava problematizar e prescrever soluções para os conflitos maritais, à medida que, ao oferecer propostas para a resolução de tais problemas, os homens de letras objetivavam legitimar o seu lugar de escrita, configurando a sua atuação como uma prática capaz de transformar a sociedade em que estavam inseridos
(Certeau, 2005). Apresentamos, a seguir, a maneira como as escritas desses intelectuais abordavam e procuravam solucionar os conflitos e ressentimentos conjugais, seja através da definição de critérios adequados para as escolhas conjugais, ou ainda, legitimando novas formas jurídicas que legalizassem a separação dos corpos e dissolvessem mesmo a sociedade conjugal, deixando homens e mulheres livres para iniciarem outros arranjos familiares.

Clodoaldo Freitas ${ }^{3}$ (in Chaves, 1998, p. 552-555) enfatiza em sua obra ficcional que o modelo de casamento por amor idealizava uma relação mais refinada do ponto de vista da conduta entre os cônjuges. As atitudes praticadas para consolidar o modelo ideal de casamento por amor apontavam para um possível nivelamento das relações entre homens e mulheres, ao realçar que as uniões fossem feitas por livre escolha. Entretanto, os papéis de gênero sofreram poucas alterações, pois as esposas permaneceram subordinadas aos maridos dentro da relação. $\mathrm{Na}$ verdade, as alterações no ideal de casamento no período que abrange o início do século XX se dão na forma como se apreende a relação marital (Costa, 2009, p. 128). Estas deveriam ser a realização de desejos íntimos, em que elementos como beleza física, empatia e cumplicidade também passavam a ter relevância no jogo de interesses que levavam à concretização da sociedade conjugal (Perrot, 1991, p. 137). Uma mulher inteiramente passiva não preenchia mais os requisitos do ideal feminino. Crescia entre os homens uma tendência a escolher mulheres que fossem companheiras nos sentimentos, nos gostos e, sobretudo, nos ideais, aliás, a incompatibilidade entre cônjuges era uma das principais razões que fomentavam a desestabilização das relações entre marido e mulher.

Após a realização do enlace matrimonial, alguns elementos podiam contribuir para o distanciamento dos cônjuges, mesmo quando o casamento era concebido desde o princípio por amor. Algumas indagações, como: o que acontecia quando os sentimentos arrefeciam e a harmonia familiar era colocada em risco, por causa de constantes conflitos domésticos? Se o amor era realmente o "laço do casamento" (Freitas, 2008, p. 39), o que seria da união familiar se a chama da paixão que envolvia marido e esposa se extinguisse ou se até mesmo ela nunca chegasse a se acender? Questionamentos semelhantes a esses afloravam do universo social e exigiam que fossem elaboradas respostas satisfatórias. Emergiam, então, alguns discursos que problematizavam a possibilidade de dissolução do casamento em casos específicos. $\mathrm{Na}$ tentativa de compreender as formas como os literatos tratavam as divergências entre os cônjuges e os discursos referentes à

${ }^{3}$ Clodoaldo Severo Conrado de Freitas (1855-1924) bacharelou-se em Direito pela Faculdade de Recife e teve uma intensa vida profissional, destacando-se como jurista, político, jornalista e literato. Possuiu vasta obra ficcional entre romances, contos e novelas publicados nos principais órgãos de imprensa das cidades de Teresina, São Luís e Belém. 
aprovação ou não da regulamentação da lei do divórcio no Brasil, passaremos a analisar alguns artigos publicados por Luiz de Morais Correia na imprensa do início do século XX, e ainda os romances Memórias de um velho ${ }^{4}$ (Freitas, 2008), Um segredo de família 5 (Freitas, 2009) e o conto O divórcio ${ }^{6}$ (Freitas, 2010), de Clodoaldo Freitas, para compreender como os literatos expressavam sua posição acerca da desarmonia familiar e da possibilidade de contestar a durabilidade de uma união formal.

O debate em torno da durabilidade do contrato matrimonial permeia a história da sociedade ocidental ao longo dos séculos. Philippe Ariès destaca que a indissolubilidade do casamento não é uma invenção da Igreja Católica; ao contrário do que muitos imaginam, a referida prática já era algo comum entre coletividades rurais da Europa por volta do século IX (Ariès, 1987, p. 163-182). Quando o clero regulamentou as uniões como um sacramento - no qual a monogamia, a negação ao ato de repudiar a esposa para contrair novo casamento e a publicação do cerimonial se tornaram elementos que legitimaram o modelo de casamento que estava sendo construído -, as resistências contra a indissolubilidade das uniões amorosas não eram tão fortes quanto o desejo de fixar o modelo sacramental de casamento que oferecia principalmente estabilidade às relações familiares.

Com o intuito de dirimir as oposições ao modelo de casamento cristão, a Igreja Católica criou mecanismos próprios, a exemplo da excomunhão, para proibir quaisquer tipos de violações das regras eclesiásticas. No entanto, as disputas para debelar a indissolubilidade do casamento atravessaram os séculos com troca de acusações entre clérigos e leigos acerca da manutenção da família, intercalando períodos de maior e menor interesse sobre o tema. No Brasil entre o final do século XIX e o início do século XX, a polêmica voltou às rodas de discussões, especialmente, após a regulamentação do casamento civil, possibilitando aos políticos e intelectuais com orientação anticlerical contestar a continuidade de uma legislação baseada em princípios católicos, quando o novo código civil, aprovado em 1911 (Melo e Marques, 2005, p. 9), tratava de um tipo de contrato marital efetuado pelo Estado.

A possibilidade de anulação do casamento era um assunto extremamente delicado para a sociedade do período que ainda tentava, através de discursos literários, religiosos, médicos e jurídicos, estabelecer a importância da união legítima entre a população. $\mathrm{O}$ esforço para ordenar os papéis sociais de homens e mulheres se realizava a partir do casamento compreendido como o estágio mais avançado das relações amorosas (Maluf e Mott,1998, p. 386), que possibilitava a regulação dos padrões de comportamento masculinos e femininos dentro de discursos moralizados e normatizados. Contudo, alguns intelectuais acreditavam que havia exceções entre as uniões maritais. Nem sempre maridos e esposas conseguiam a oportunidade de um convívio ideal, por causa da ocorrência de incompatibilidade de gênios entre os cônjuges. Nesses casos, a inexistência de uma legislação que oportunizasse a separação e a regularização das partes envolvidas provocava descontentamento diante do impasse que os casais teriam que suportar durante toda a sua vida.

Clodoaldo Freitas é um dos literatos que remete ao tema, como no exemplo do romance Memórias de um velho. No enredo, Milo, o protagonista do romance, fixou residência em uma cidade do interior piauiense e, após contrair matrimônio com Guilhermina, acabou se desiludindo com os desentendimentos diários com a esposa. Os anos iniciais desse casamento mostraram-se muito prósperos, consolidados com o nascimento dos dois filhos do casal. Entretanto, segundo o narrador, a felicidade conjugal foi abalada pelo caráter genioso da esposa. Ciumenta e inflexível com relação à autoridade do marido, Guilhermina tornava a vida conjugal insuportável por causa dos conflitos cotidianos com Milo. A situação ficou ainda mais insustentável com a emergência de uma desavença religiosa entre os cônjuges, pois, apesar das advertências do marido - que era maçom e defendia publicamente as suas orientações anticlericais -, Guilhermina insistia em desafiar o esposo, praticando o sacramento da confissão, assistindo às missas na igreja e ingressando no Apostolado do Coração de Jesus.

As descrições dos conflitos feitas pelo protagonista de Memórias de um velho realçam o quanto poderia ser nociva para a estabilidade conjugal a geniosidade de uma mulher. Uma esposa ideal deveria possuir qualidades físicas e morais, como a beleza física, a simplicidade, a modéstia e a disposição para o trabalho; no entanto, para além desses dotes, era imprescindível que assumisse certa postura de submissão ao marido, condição sine qua non para manter a harmonia do casal, haja vista que o papel de orientador da esposa e dos filhos era um dos elementos definidores da masculinidade moderna que estava surgindo (Castelo Branco, 2005). O comando das relações familiares deveria

${ }^{4}$ Conto publicado pela primeira vez em folhetins no jornal Pátria da cidade de Teresina entre os dias 30 de novembro de 1905 e 9 de fevereiro de 1906 . Em 2008 os folhetins foram reunidos e publicados na forma de livro. Deste ponto em diante utilizaremos a sua publicação mais recente para fazer referência a esta obra no texto.

${ }^{5}$ Conto publicado pela primeira vez em folhetins no jornal Diário do Maranhão da cidade de São Luís entre os dias 7 e 14 de outubro do ano de 1907 . Em 2009 foi relançado dentro da coletânea Um segredo de família e outros contos.

${ }^{6}$ Conto publicado pela primeira vez em folhetins no jornal Pacotilha da cidade de Teresina entre os dias 5 e 7 de setembro do ano de 1907 . Em 2010 foi relançado dentro da coletânea Os burgos e outros contos. 
concentrar-se nas figuras masculinas, e tentar subverter essa ordem constituía uma afronta à virilidade e, por conseguinte, uma alusão de que marido e mulher poderiam ocupar um mesmo nível no que diz respeito aos direitos e obrigações conjugais. Deste modo, como o personagem Milo não conseguia exercer a sua autoridade masculina, orientando as decisões da esposa, o término do casamento configurava-se para ele como a solução mais sensata para a ocasião, pois uma ação enérgica e até mesmo mais violenta para contornar a personalidade inflexível e tirânica de Guilhermina poderia ser compreendida como uma forma equivocada e incivilizada de conduzir as relações familiares.

\section{[...] Que diabo! Tudo tem um limite, principalmente a} paciência humana. O homem não deve bater na mulher sequer com uma pétala de rosa, diz o adágio antigo; mas há casos em que deve bater com um pedaço de pau. Há mulheres que só prestam apanhando. Provocam o marido, e, no dia em que apanham, se abrandam, se humanizam, tornam-se uns anjos de bondade. Guilhermina seria destas? Creio que sim.

Eu não tinha a energia suficiente, ou, antes, tinha medo do escândalo.

Dar na esposa! Que horror! Mas ou dar, ou abandonar ou matar. O melhor era abandonar sem estardalhaço, sem alarde. Depois, podiam fervilhar os comentários. Seriam tardios e inúteis (Freitas, 2008, p. 69-70).

Milo não estava inserido em um padrão de masculinidade tradicional, cuja forma de confirmar a autoridade de chefe da família era através da agressão verbal e física (Albuquerque Júnior, 2005, p.153-181). O próprio personagem ressalta que a possibilidade de corrigir a esposa de maneira enérgica era uma prática em desuso e apontada como um hábito incivilizado. Milo decide partir para outra estratégia, ao tentar vivenciar uma rotina doméstica mais sossegada: ele cumpre as ameaças feitas e parte com os filhos para outra cidade, abandonando a esposa. Esta seria uma chance para recomeçar, se não fosse a queda moral na qual Guilhermina mergulhou. Sozinha, ela não consegue administrar os próprios recursos financeiros e, inconsequentemente, doa todos os bens materiais que possuía para a Igreja. Aos poucos, os desgostos pela vida solitária longe do marido e dos filhos afetam essa mulher de maneira fatal e a mesma acaba entregando-se ao alcoolismo e, por fim, à loucura. Fora de si, Guilhermina assassina os próprios filhos e, ao se deparar com a triste cena dos descendentes já sem vida ao lado da mãe insana, Milo, movido por impulso, acaba matando a própria esposa. Clodoaldo Freitas descreve esse trágico acontecimento como um alerta, para apontar os riscos que a dissolução da família poderia trazer para os seus componentes.
Guilhermina comete um erro ao preferir frequentar a Igreja a cuidar da sua família, e essa falha no papel de mãe e esposa é corrigida com o rebaixamento da mesma como modelo feminino. Ou seja, de respeitada mãe de família, Guilhermina passa à condição de mulher abandonada pelo marido, miserável e louca.

Passado o luto pela perda dos filhos, Milo reerguese e toma gosto pela vida política. Após um reencontro emocionante com Josefina, de quem havia sido amante no passado, o personagem percebe que aquela relação poderia finalmente ser concretizada, pois Milo se dispunha a amar Josefina independentemente de sua condição física e financeira. Os dois se casam, e o romance encerra-se com a partida do casal e dos pais de Josefina, para uma temporada na Europa. Nesse desfecho de Memórias de um velho nos chama atenção a forma como Milo opta pelo casamento. $\mathrm{O}$ casal poderia ter contraído matrimônio, anos antes, quando Josefina havia ficado viúva, e eles poderiam assumir a relação amorosa que eles ocultavam. Naquele momento não havia impedimentos, mas a incerteza dos sentimentos de Milo o levaram a desistir daquele relacionamento e aguardar por um momento mais promissor. Por sua vez, Josefina, apesar de consternada com a partida do amado, não faz exigências, nem protesta e aguarda pacientemente para ver suas esperanças de se casar novamente se materializarem. São o amor e a passividade de Josefina que motivam Milo a investir em uma nova relação, após o reencontro dos dois. A maturidade do protagonista permitia compreender que a dedicação extremada, os gostos refinados e a boa condição financeira da nova esposa eram elementos que contribuíam para a construção de uma paz conjugal que não havia sido alcançada no seu relacionamento anterior com Guilhermina.

Clodoaldo Freitas explora o assunto da possibilidade de dissolução do matrimônio também em Um segredo de família, ao levantar a discussão sobre o destino de Dr. Anastácio Dias e Ângela, vivendo uma relação insustentável que culminou com a separação do casal. A história começa na cidade do Rio de Janeiro, onde o protagonista, Dr. Anastácio Dias, recebe a irrecusável proposta de um rico senhor, chamado Tertuliano das Neves: desposar no final daquele mesmo dia Ângela, a sua única filha. Anastácio é conduzido à casa daquele senhor, que conhecia apenas de vista em casa de seu melhor amigo, Ernesto, para ser apresentado à sua pretendente e surpreende-se ao descobrir que suas malas já estavam em seu novo quarto e que a cerimônia estava planejada para acontecer naquela mesma noite. Afinal, o jovem cede à proposta feita, mesmo sem saber os motivos reais da realização de uma cerimônia de casamento de forma apressada.

Quinze dias depois, os problemas começaram a aparecer entre Anastácio e Ângela. A nova esposa 
mostrava-se muito imperiosa reprovando as ações do marido em público na companhia de amigos, provocando dessa maneira um mal-estar entre o casal. A solução para Anastácio era tentar ensinar Ângela e adequá-la à nova situação em que se encontrava, ou seja, era preciso lembrá-de la que uma das principais obrigações femininas era saber ouvir o marido. $\mathrm{Na}$ primeira oportunidade, o protagonista adverte a consorte:

[...] Poucos dias depois, como ela mostrasse desejo de ir à rua durante o dia e à noite ao teatro, eu não concordei com a sua vontade e declarei-lhe positivamente que ela não sairia sozinha, nem iríamos ao teatro.

- Por quê? - perguntou ela.

- Porque eu não quero.

- É uma razão grosseira de quem não tem razão.

- Sic jubeo, sic volo.?

- Não faço conta do seu latim.

- Nem eu cito latim para a senhora fazer conta! Mas

precisamos assentar, de uma vez, certas regras da nossa vida. Quer a senhora obedecer-me como marido e chefe de familia?

- A que vem tudo isto?

- Simplesmente daquela atitude singular em casa de Ernesto.

- Ab! É uma vingança.

- Não, é uma lição. Precisava entender-me com a senhora. Pois não se lembra que foi severa e me fez, para não dar escândalo, tragar a vergonha pública de sua invectiva?

- Não tive propósito de ofendê-lo.

- Bem sei, mas foi cruel.

- Desculpe-me.

- Não tem de quê. Mas, como não tivemos tempo de nos conhecermos reciprocamente em solteiros, vamos aproveitar este ensejo para regularmos as nossas respectivas posiçöes, direitos e deveres. Antes de tudo, devo-lhe confessar meus vicios. Sou ciumento e desconfiado, suscetivel e vingativo. Como virtude, creio ter generosidade, lealdade, abnegação e franqueza. Não compreendo essa civilização de andar uma senhora sozinha pela rua ou acompanhada pelos amigos do marido. Por isto lhe previno que só sairá comigo ou com seu pai. No mais, toda liberdade dentro dos limites do honesto (Freitas, 2009, p. 29-30).

Para descontentamento de Anastácio, a tentativa de corrigir os modos da esposa foi frustrada, pois Ângela recusou-se a aceitar as imposições do marido e, ao fim da discussão, o despreza pedindo a separação. Neste romance, Clodoaldo Freitas aponta algumas motivações que poderiam conduzir ao desgaste de um casamento; trata-se, por exemplo, da própria forma como o mesmo fora feito, sinalizando uma forma inadequada de iniciar uma relação a partir do modelo de amor romântico. $\mathrm{O}$ casamento entre Anastácio e Ângela fora feito por interesse: ele queria um dote e ela o nome de um marido, porém nada mais foi levado em consideração, para a constituição dessa nova família; nessas condições, o casamento dificilmente poderia obter felicidade, pois o amor não teve a oportunidade de ser cultivado. A geniosidade de Ângela também pode ser vista como uma das razões que produziram uma desarmonia entre o casal, pois, dentro do casamento, a esposa deveria exercer certas aptidões consideradas como naturais ao sexo feminino, como agradar (Carvalho, 1909, p. 35). Destarte, a abnegação inseria-se entre as virtudes da mulher para confirmar o posicionamento de cada cônjuge na relação, sendo o homem considerado o chefe do lar que exerceria poder sobre os outros familiares. Quando Ângela desprezava o próprio marido, ela quebrava o discurso estabelecido que legitimava a subserviência feminina.

Nesse romance, é também flagrante uma inversão de papéis sexuais observada não somente na postura imperiosa de Ângela perante o marido, como também pelo seu apego às coisas mundanas. Clodoaldo Freitas condenava o excessivo envolvimento das mulheres nos lazeres modernos (Freitas, 1996, p. 72-73). Os passeios, as idas ao teatro revelavam, na verdade, o abandono do lar pelas mulheres que estariam cada vez mais envolvidas com o luxo e a ostentação, enquanto desprezavam os maridos, filhos e tudo aquilo que estava relacionado ao ambiente doméstico. Por sua vez, Anastácio representava, frente à agressividade da esposa, uma tendência ao afeminamento, transformando-se em um simples objeto, por não conseguir exercer uma postura firme e fazer-se respeitado como chefe de família.

O casal decide manter as aparências diante dos amigos, mas, apesar das súplicas do pai para convencer a filha a conviverem na mesma casa, Anastácio e Ângela dormem em quartos separados e pouco se falam. Decepcionado com o fim do casamento, Anastácio decide voltar para a cidade de Amarante, no interior do Piauí, para atender a um pedido da mãe, que se encontrava doente, e comandar a fazenda da família. Ao regressar, Anastácio revela aos familiares que havia sido pressionado para se casar com uma moça rica, mas esta o humilhava constantemente, e que, um mês depois, já estavam separados. A revelação surpreende a todos, especialmente a sua prima

7 "Quero-o, ordeno-o". Do poeta Juvenal, as palavras são citadas quando se alude a uma vontade arbitrária e despótica. 
Luizinha, sua noiva desde a infância e que, mesmo depois de anos, ainda nutria esperanças de se casar com Anastácio. Nesse trecho do enredo, Clodoaldo Freitas apresenta uma solução para a infelicidade de Anastácio: um segundo casamento. Joca, o pai de Luizinha, reverte a situação do sobrinho, ao falsificar, no livro de registros da localidade, a data do casamento dos primos, anterior à sua união com Ângela no Rio de Janeiro; dessa maneira, não se poderia contestar legalmente o segundo casamento. Nesse caso, o amor pode ser contemplado, e Anastácio e Luizinha puderam ser felizes naquela nova união.

A seguir, o romance apresenta uma série de revelações que vão esclarecer alguns acontecimentos que ficaram sem explicação, como o casamento repentino entre Anastácio e Ângela. Tempos depois, o velho Tertuliano aparece de surpresa na fazenda e relata a Anastácio que o casamento fora obra de uma armação entre Ângela e Ernesto, que mantinham um caso amoroso e desejavam encobrir uma gravidez, haja vista que, depois da partida do marido para o Piauí, Ângela descobre que estava grávida novamente e como não havia conseguido fazer com que Anastácio retornasse para o Rio de Janeiro, auxiliada por Ernesto, ela inventa uma viagem para ocultar a gestação; entretanto, a farsa é descoberta, quando ela morre logo após o parto. Tertuliano faz ainda a revelação final: era o verdadeiro pai de Anastácio. Por causa de uma intriga familiar no passado, abandonara a esposa e, no Rio de Janeiro, casou-se novamente com a mãe de Ângela, que já estava grávida de outro homem. A intenção de casá-lo com a filha adotiva era apenas para ter o filho legítimo Anastácio - mais próximo de si. A história é encerrada após Anastácio conseguir a reconciliação entre o pai e o tio, estabelecendo a paz e a harmonia familiar naquela fazenda.

O que nos interessa em Um segredo de família é o episódio em que Anastácio consegue uma nova chance para ser feliz forjando um segundo casamento. A lei de fato não permitia o divórcio, contudo não possuía total controle sobre outras formas de relacionamentos, como o amasiamento e o concubinato, que sempre tiveram recorrência especialmente entre os grupos sociais de menor poder aquisitivo (Del Priore, 2000). Nesse romance, Clodoaldo Freitas aponta os dissabores que um indivíduo poderia suportar com um matrimônio infeliz, pois, além de sofrer pelas desavenças maritais, ainda teria que se resignar por estar legalmente impedido de constituir uma nova família.

Abdias $\mathrm{Neves}^{8}$ é outro literato que, nas primeiras décadas do século XX, registra seus posicionamentos acerca do tema, agrupando-se entre aqueles caracterizados como livre-pensadores. No artigo A opinião pública e o divórcio, publicado na revista Litericultura, da cidade de Teresina, expressa sua opinião contestando o posicionamento da Igreja Católica, que impedia a criação de uma legislação que contemplasse cônjuges que desejassem, por mútuo consentimento, anular o casamento. $\mathrm{O}$ seu argumento direcionava-se no sentido de desconstruir o discurso católico de que as mudanças na legislação, com a legalização do divórcio, promoveriam um progressivo aumento dos casos da poligamia e de devassidão na sociedade.

Antes de tudo, nenhuma razão explica, a não ser o preconceito religioso, que o decreto permitisse a separação indefinida dos corpos e mantivesse a indissolubilidade do vinculo. Trata-se de uma medida de ordem social: mas, onde o interesse da sociedade [está] quando permite que se separem dois cônjuges - está em proibir que se possam casar novamente e constituir, deste modo, duas uniões ilegitimas, ou está em lhes proibir essa união - deixando-lhes aberta, somente, a porta do concubinato? Onde o maior inconveniente, em que se casem, ou em que constituam as uniões ilegitimas? [...] Pretender, por outro lado, que os costumes se corrompam com a simples promulgação da lei que o estabeleça, é pretender que são as leis que fazem os costumes - quando a verdade é que são estes que determinam aquelas. Leis não modificam costumes. Se deles não são um reflexo, nenbuma influência sobre eles exercem. É princípio corrente que não precisa de demonstração. Deste modo, se somos um povo moralizado, moralizado continuaremos. Se não somos, não será a falta de um decreto legislativo que corrija os nossos costumes e evite o pendor para a degradação. E, num caso e no outro, nada impede que os aceitemos [...] (Neves, 1912, p. 209).

Outro literato que também fez coro a favor do divórcio foi Cândido Gil Castelo Branco, ${ }^{9}$ mas usando em sua escrita um tom cômico, a partir de pilhérias (Castelo Branco, 1912, p. 209-211). Segundo ele, a preocupação em torno da mulher, que seria a mais prejudicada com a separação, não teria argumentos concretos, pois dificilmente ocorreriam casos em que a mulher seria abandonada a esmo, sem que nenhuma razão sensata fosse apresentada pelo marido. Para o autor, somente alguns casamentos eram fonte de dissabores, e, portanto, seriam poucos os homens que se arriscariam a sair de uma união feliz, para investir em outra; por isso, as

\footnotetext{
${ }^{8}$ Abdias da Costa Neves (1876-1928). Bacharel em Direito, professor, juiz de direito, procurador, senador da República, historiador e romancista, com destaque para a obra Um manicaca (1985 [1909]).

${ }_{9}^{9}$ Cândido Gil Castelo Branco nasceu no ano de 1820, em José de Freitas (PI). Professor, magistrado, deputado provincial (1844-1849), deputado-geral (1881-1885) e desembargador do Tribunal de Justiça.
} 
mulheres não teriam o que temer, afinal, as estatísticas e os próprios costumes apontavam que o pedido de separação era feito apenas em casos extremos. "[...] Mas qual será o doido que se dando bem interrompa o seu idílio ou que se dando mal queira reproduzir o erro?" (Castelo Branco, 1912, p. 209), argumentava o autor, completando que o divórcio deveria ser estabelecido em forma de lei, para atender casos em que havia uma clara incompatibilidade de gênios entre o casal, devendo o Estado intervir pelo bem-estar dos filhos daqueles relacionamentos.

Outro aspecto trazido por Castelo Branco é a ideia de inversão de papéis que ameaçava o casamento. Ironicamente o literato descreve o primeiro divórcio do mundo realizado entre o sol e a lua: no início tudo corria harmonicamente, mas o sol acabou se queixando a Deus porque não conseguia conviver com uma companheira que se levantava quando ele deitava e se deitava quando ele dormia, que vivia mudando de quarto e aparecia todos os meses cheia apesar de nunca se encontrarem. A história funciona como uma sátira sobre a vida conjugal, na qual homens e mulheres enfrentavam continuamente os empecilhos impostos pela vida moderna que permitia a inserção da mulher no espaço público, enquanto o homem tentava se adaptar ao lar, de onde a figura feminina estaria cada vez mais ausente.

E quando a mulher, como a lua, começar a devanear, ir para os seus firts e regatas, clubs e pic-nics, deixando em casa os seus bebês ao cuidado das criadas, enquanto o marido, como o sol, que se recolhe manicacamente ${ }^{10}$ às 6 da tarde, depois de um dia inteiro de trabalbo? São exceçôes, me dirão.

Mas é exatamente para os casos excepcionais que se procura estabelecer e regular o divórcio. Ele terá os seus casos restritos (Castelo Branco, 1912, p. 210).

Seria, então, nessas situações que o Estado poderia intervir, quando havia a clara impossibilidade de reconciliação entre as partes interessadas. A situação descrita sugeria que as famílias enfrentavam problemas e caberia à Justiça solucionar as dissensões domésticas. Para concluir seus argumentos, o autor cita um verso de Simplício Lopes Castelo Branco e o oferece a todos aqueles que desejavam casamento e àqueles que intencionavam sair dele. Eis os versos:

Quem se casar neste mundo,

Não more aos pés de sogro nem de sogra,
Porque o sossego não logra.

Urra o sogro, berra a sogra,

Grita a filha destemida,

Acode a chusma atrevida
De cunbados fariseus...

Escapa um homem com vida

Por um milagre de Deus (Castelo Branco, 1912, p. 211).

Os versos aludem a um dos fatores que possibilitariam as divergências entre maridos e esposas; trata-se da intromissão de familiares na vida particular dos cônjuges. Percebemos, nessas linhas irônicas, a valorização do modelo familiar moderno, no qual apenas o casal e os filhos compunham esse ideal. A presença de terceiros no âmbito familiar remete à representação da família colonial, a qual reunia várias gerações em um mesmo domicílio. Contudo, ao contrário do que o aburguesamento dos costumes sugeria, o envolvimento de outros familiares na vida íntima do casal indicava que ainda havia uma ausência de privacidade nas relações. Maria Ângela D’Iancao reforça essa questão, analisando as representações familiares na literatura brasileira oitocentista, ao revelar que as relações entre família e tudo o que estava em volta eram ainda muito próximas (D'Iancao, 1996, p. 32), muito embora os literatos acreditassem que a manutenção da harmonia conjugal dependia da conservação da vida particular do casal.

No conto O divórcio, Clodoaldo Freitas oportuniza novamente a discussão, mas, desta vez, enfatizando o dilema de indivíduos que passam a vida atormentados pelo fato de estarem presos permanentemente a uma união indesejável. No enredo, situado na cidade de São Luís (MA), o protagonista, o Conselheiro Evaristo Reis, desabafa a sua infelicidade ao amigo Dr. Pedro Caldas, após ser comunicado da morte de Quinoca, com quem estava vivendo há mais de 30 anos, período, segundo ele, permeado de tormentos para ambas as partes. Para o conselheiro, a morte da esposa chegava tardiamente, pois os desejos de contrair novo matrimônio existiram apenas enquanto ainda havia mocidade; agora a velhice impedia as chances de se casar novamente e tentar ser feliz. Do amor desfrutado no início da relação aos ressentimentos multiplicados em anos de conflitos, o casamento de Evaristo e Quinoca tornou-se um exemplo de incompatibilidade de gênios, no qual a convivência se transformou em algo insuportável. Evaristo expressava muitas mágoas, ao relembrar sua convivência com a esposa:

- [...] Casei-me por amor como tantos rapazes sem
juizo, que comęam a vida por essa loucura e mostram,
desde logo, que não têm o verdadeiro critério prático.
O casamento por amor é a maior das tolices humanas
e a fonte, em regra, de todas as nossas desgraças. O
casamento deve ser um negócio de conveniência e de
bom senso. Casei-me enão se passaram dois meses que

${ }^{10}$ Uma alusão à palavra manicaca, um termo popular da época que se refere a um indivíduo desfibrado e controlado pela mulher. 
não me arrependesse do passo errado que dei. Apelei para Deus, esperando que ele corrigisse o meu erro, desfazendo-o no primeiro parto da minha Quinoca. Mas veio o primeiro, o segundo, até o décimo parto sem que Deus olhasse para mim! Durante esse longo tempo minhas súplicas eram cada vez mais ardentes, porque cada vez mais me tornava desgraçado no meu casamento.

Deus fez ouvidos de mercador e parece que, em meu castigo, tornava a minha Quinoca cada vez mais atrabiliosa e ciumenta. Uma mulher ciumenta épior do que a lepra. Um casamento infelizé de todas as maldiçôes de Deus, a mais severa, éum mal de todas as horas sem ventura de uma hora sequer. O lar transformado em inferno! Meu amigo, eu fui um excomungado de Deus, porque aguentei uma tal esposa por espaço de trinta anos. Um acúmulo de dores [...] (Freitas, 2010, p. 36).

O trecho acima trata dos discursos que apontam as razões para a infelicidade conjugal. Para Evaristo, o primeiro erro foi o fato de ter contraído casamento apenas por amor, colocando a racionalidade em segundo plano. Dessa forma, ampliaram-se as chances de insucesso, pois o sentimento não deveria ser o único critério para a escolha de um cônjuge (Costa, 2009, p. 128).

Além disso, a conduta inapropriada da esposa também foi apontada como uma das principais razões para a situação insuportável em que o casal se encontrava. Nesse caso, o conto representa a posição masculina mostrando apenas o lado de Evaristo, indicando a mulher como a maior responsável pela desarmonia conjugal, por nada ter feito para estabilizar o relacionamento. Para ele, Quinoca procurava encontrar motivos para irritar o marido e mantê-lo longe do lar desobedecendo à sua posição como chefe de família e ainda desprezando o esposo, ao aproximar-se das práticas religiosas que o incomodavam, como o sacramento da confissão. Clodoaldo Freitas não permite conhecer o outro lado da moeda, pois não dá voz a Quinoca dentro do enredo, enfatizando um discurso que vincula a forma como se desenvolve a participação feminina dentro do casamento ao nível de felicidade marital. Nesse sentido, o autor destaca que "[...] a primeira religião de uma honesta mãe de família são o marido, os filhos, a paz doméstica" (Freitas, 2010, p. 38) para lembrar que o fracasso da mulher desempenhando o papel de esposa teria resultados diretos na família. Desse modo, os esforços desenvolvidos para afastar o interesse feminino de tudo aquilo que não se referia ao lar eram realçados na forma de discursos, para orientar que a decadência da família dependia especialmente da postura feminina (Castelo Branco, 1996, p. 11).

Nos documentos tratados até agora, os literatos assumem posturas que culpabilizam as mulheres pela infelicidade conjugal; faltaria a algumas delas a sabedoria necessária para harmonizar o seu lar e, assim, manter a vida conjugal dentro de parâmetros de convivência gratificantes ou, pelo menos, suportáveis para homens e mulheres. Em outras produções textuais, a problemática dos conflitos conjugais ganha outras cores; em Astúcia de mulher ${ }^{11}$, peça teatral de costumes teresinenses, escrita por Jônatas Batista $^{12}$, os conflitos e a decepção com a vida conjugal são motivados pelas atitudes masculinas do personagem Jorge, jovem recém-casado com a personagem Laura, mas que procura manter intactas suas sociabilidades masculinas, vivenciadas antes de contrair matrimônio.

É realmente para desesperar!... casa-se a gente esperando um paraíso de delicias, um céu constante de gozos e felicidades, para depois, mal passado os quinze primeiros dias ter saudade da vida de solteira. Ainda não tenho seis meses de casada, ejá me queixo da sorte. Noites inteiras completamente isolada, a me rolar na cama, ouvindo o tic-tac monótono do relógio, enquanto Jorge (o esposo) cruel e desumano vive do clube para as farras, dos bailes para o jogo! Hoje ainda não veio jantar. Diz que precisa se divertir é muito natural; mas eu vegeto, envelheço de insipidez, morro de tédio, de aborrecimento (Batista, 1925).

Jônatas Batista retrata na personagem Laura um modelo feminino que incorpora o casamento e a vida conjugal como espaço caracterizado pela presença do afeto, do amor romântico, mas que exige e espera o envolvimento emocional do marido. A desilusão da personagem Laura vem exatamente do descompromisso masculino com a vida conjugal, com a vivência em sintonia com a mulher. Contudo, Laura não cogita do divórcio, não vislumbra nele a possibilidade de iniciar nova vida, de buscar a felicidade conjugal com outro homem.

O autor constrói as expectativas de vida de Laura dentro do que a moral social esperava das mulheres no período, ou seja, que cultivassem a percepção de que o fracasso na vida conjugal seria o fracasso do próprio projeto de vida, de ser percebida como uma mulher incapaz de manter o casamento e manter o marido, colocando em risco sua subsistência e a da sua prole, o nome da família.

\footnotetext{
11 Comédia apresentada no ano de 1925; também foi publicada em folheto no decorrer daquele mesmo ano.

${ }^{12}$ Jônatas Batista (1885-1935) exerceu diferentes cargos públicos, atuou ainda como jornalista, poeta, teatrólogo e foi um dos fundadores da Academia Piauiense de Letras. Destacou-se no cenário cultural piauiense por suas peças teatrais, a exemplo de O bicho, Jovita e a comédia Astúcia de mulher.
} 
O texto de Jônatas Batista pode ser lido ainda como um alerta para os homens; era preciso que ficassem atentos às suas práticas e às nefastas consequências que elas poderiam ter no espaço da casa, provocando a insatisfação feminina com a vida conjugal. Era preciso que os homens também se sentissem corresponsáveis pela harmonia da casa, mesmo que essa continuasse a ser uma responsabilidade feminina.

Além de problematizar as relações conjugais em suas obras ficcionais, os literatos também utilizavam sua escrita para argumentar favorável ou desfavoravelmente à legalização do divórcio. É assim que, no início do século XX, Luiz Moraes de Correia ${ }^{13}$, dissertando sobre o assunto em uma série de artigos publicados no Diário do Piauí intitulados "O divórcio", posicionou-se favoravelmente à aprovação de uma legislação que permitisse regulamentar a anulação do casamento. ${ }^{14} \mathrm{O}$ jurista assumia, assim, opinião favorável à modificação da legislação vigente no Brasil, pois a lei em vigor se limitava a autorizar apenas a separação indefinida de corpos e de bens entre os casais, mas novas núpcias não poderiam ser contraídas com base no princípio da indissolubilidade dos laços conjugais defendido por prestigiados juristas brasileiros como Beviláqua (1959).

O projeto de lei do divórcio ofereceria, dentre outras coisas, a proteção do Estado para os envolvidos, em especial para a mulher e para os filhos, e possibilitaria especialmente para aqueles que ainda desejavam investir na vida conjugal a chance de constituir legalmente uma nova família, sem precisar recorrer a uniões ilícitas, como a mancebia. A polêmica questão transcorreu durante as décadas seguintes do século $\mathrm{XX}$, sem que houvesse uma alteração que materializasse o anseio dos que defendiam a dissolubilidade do casamento civil - ocorrida no Brasil somente em 1977 (Melo e Marques, 2005). Por sua vez, a literatura acabou se configurando como um dos canais que exploraram o impasse constituído por esposos infelizes.

Se o divórcio conquistava a aprovação de pessoas, como Luiz Correia, para outros, a aprovação do divórcio traria para a convivência social no futuro situações inusitadas e, para os padrões morais da época, inaceitáveis. No jornal O Apóstolo, de 1913, na crônica "Os divorciados", podemos perceber como o divórcio era também estigmatizado como algo devastador aos modelos familiares:

\section{[...] Fui ao baile em outubro de 1938, suponbam façam de conta [...] \\ Pelo Conselheiro Faustino foram me apresentadas três senhoritas:}

- Minhas filhas, ilustre Crispim.

- E minhas também diz o companheiro da esquerda...

- Mas, perdão, não compreendo...

- Ora não tem nada que compreender: eu fui casado com a mãe delas, portanto são minhas filhas. Ora, como eu resolvi mudar de mulher, e o conselheiro se agradou da supra-dita cuja, ficam sendo agora as pequenas filhas do conselheiro...

- Levei minha mulher, resolvido a abandonar aquele meio estragado.

- Adeus, casta esposa! - Segreda baixinho um figurão, dai a instantes.

Levanto a bengala raivoso.

- Perdão, essa senhora é minha legitima esposa; mas é que eu requeri divórcio e a pomba levantou asa. Agora ésua, mas já foi minha...

- Mas, ó Eufrasia quantas vezes casaste tu já?

- O menino, pois tu admiraste? Oito maridos já tive eu, contigo nove, e olha que não tenho vontade de ficar por aqui... (O Apóstolo, n. 273, p. 3).

O que encontramos no conjunto literário analisado é a tentativa de buscar um equilíbrio entre os sentimentos e a razão como critérios para ingressar e permanecer na vida marital. A polêmica aberta acerca da aprovação ou não de uma regulamentação da separação civil no início do século XX é interessante, quando percebemos que a família era problema central na escrita dos literatos piauienses, independentemente da formação moral que estes defendiam, uma vez que a escrita analisada neste estudo apresentou homens de letras que definiam seus padrões familiares a partir da apreciação de valores tradicionais, mas, sobretudo, de práticas discursivas pautadas na racionalidade e orientadas especialmente pelo movimento anticlerical.

A preocupação em proteger o recinto do lar - preservando a união dos cônjuges ou resguardando os direitos individuais do casal e da prole - significava que, no período aludido, o aburguesamento dos costumes possibilitou uma idealização da família e de seus integrantes. A escrita dos intelectuais abordados, ao longo deste artigo, revelou o desejo de proteger o núcleo familiar das ameaças morais constantes a exemplo das paixões incontroláveis, do adultério e dos filhos ilegítimos. A proposta do divórcio apresentada por aqueles homens de letras não estava relacionada a uma revolução de costumes; pelo contrário, os textos de natureza jurídica ou literária mostram sempre uma postura tradicional em relação aos papéis familiares, sobretudo, em deixar claro que a subserviência feminina

\footnotetext{
${ }^{13}$ Luiz de Moraes Correia (1881-1934), professor, magistrado, jurista e jornalista. Algumas de suas obras publicadas: $O$ Habeas-Corpus e os interditos, $O$ crime $e$ a pena, $O$ divórcio, A questão social, $O$ Porto de Amarração, $O$ amor e o crime, dentre outros.

${ }^{14} \mathrm{Em} 1912$ o jurista reuniu os seus artigos sobre o tema e publicou livro com o título $\boldsymbol{O}$ divórcio (Correia, 1912).
} 
deveria ser uma regra geral dentro do relacionamento marido e mulher. Na verdade, o elemento inovador dessa luta pela dissolubilidade do matrimônio estava em mostrar à sociedade que a durabilidade do casamento não precisava mais ser baseada em meros contratos, como ocorria, com certa predominância, até o referido momento, pois, no lugar daqueles, o casamento por amor surgia como nova proposta para a criação e manutenção dos laços entre cônjuges suplantando qualquer receio que o divórcio pudesse produzir.

\section{Referências}

ALBUQUERQUE JÚNIOR, D.M. de. 2005. De fogo morto: mudança social e crise dos padrões tradicionais de masculinidade no Nordeste do começo do século XX. História Revista, 10(1):153-181.

ARIÈS, P. 1987. O casamento indissolúvel. In: P. ÁRIES; A. BÉJIN (Orgs.), Sexualidades ocidentais: contribuiçôes para a história e para a sociologia da sexualidade. $3^{a}$ ed., São Paulo, Brasiliense, p. 163-182.

BATISTA, J. 1925. Astúcia de mulher. Teresina, s. n.

BEVILÁQUA, C. 1959. Direito da família. 9a ed., Rio de Janeiro/São Paulo, Editora Livraria Freitas Bastos, 424 p.

CARVALHO, M.A.V. de. 1909. A arte de viver na sociedade. $4^{\mathrm{a}}$ ed., Lisboa, Parceria Antonio Maria Pereira Editora, 249 p.

CASTELO BRANCO, C.G.1912. O divórcio. Litericultura, 1(3):209211.

CASTELO BRANCO, P.V.1996. Mulheres plurais: a condição feminina em Teresina na Primeira República. Teresina, Fundação Cultural Monsenhor Chaves, $147 \mathrm{p}$.

CASTELO BRANCO,P.V.2005. Masculinidades plurais: a construção das identidades de gênero em obras literárias. História Unisinos, 9(2): 85-95.

CERTEAU, M. de. 2005. A invenção do cotidiano: artes de fazer. Petrópolis, Vozes, vol. 1, $351 \mathrm{p}$.

CHAVES, J. 1998. Clodoaldo Severo Conrado de Freitas. In: J. CHAVES, Obra completa. 2a ed., Teresina, Fundação Cultural Monsenhor Chaves, p. 552-555.
CORREIA, L. de M. 1912. O divórcio. Teresina, Imprensa Oficial, 52 p. COSTA, M.L.F.2009. Pedagogia dos sentimentos: as relações de gênero na obra de Clodoaldo Freitas. In: P.V. CASTELO BRANCO (org.), História e fição. Imperatriz, Ética, p. 115-130.

D’IANCAO, M.Â. 1996. Sentimentos modernos e família. São Paulo, Brasiliense, $158 \mathrm{p}$.

DEL PRIORE, M. 2000. História do amor no Brasil. São Paulo, Contexto, $330 \mathrm{p}$.

FREITAS, C. 1996. Em roda dos fatos. 2a ed.,Teresina, Fundação Cultural Monsenhor Chaves, $191 \mathrm{p}$.

FREITAS, C. 2008. Memórias de um velho. Imperatriz, Ética, 105 p.

FREITAS, C. 2009. Um segredo de família. In: C. FREITAS, Um segredo de família e outros contos. Imperatriz, Ética, p. 23-44.

FREITAS, C. 2010. O divórcio. In: C. FREITAS, Os burgos e outros contos. Imperatriz, Ética, p. 35-45.

MALUF, M.; MOTT, M.L. 1998. Recônditos do mundo feminino. In: N. SEVCENKO (org), História da vida privada no Brasil: República: da Belle Époque à Era do Rádio. São Paulo, Companhia das Letras, vol. 3, p. 367-421.

MELO, H.P. de; MARQUES, T.C.N. 2005. Que sejam felizes para sempre! A mulher e seus direitos na sociedade conjugal: um exame do Estatuto da Mulher Casada de 1962. In: CONGRESSO BRASILEIRO DE HISTÓRIA ECONÔMICA, VI, Conservatória, 2005. Anais... Niterói, 2005, ABPHE/EDUFF, p. 1-29.

NEVES, A. 1985 [1909]. Um manicaca. Teresina, Projeto Petrônio Portella, 209 p.

NEVES, A. 1912. A opinião pública e o divórcio. Litericultura, 1(3):200208.

O APÓSTOLO. 1913. Os divorciados. Teresina, n. 273, p. 3.

PERROT, M. 1991. Figuras e papéis. In: M. PERROT (org.), História da vida privada: da Revolução Francesa à Primeira Guerra. São Paulo, Companhia das Letras, vol. 4, p. 121-185.

SEVCENKO, N. 2003. Literatura como missão: tensões sociais e criação cultural na Primeira República. 2a ed., São Paulo, Companhia das Letras, $420 \mathrm{p}$.

Submetido em: 21/09/2010 Aceito em: 21/03/2011

Mara Lígia Fernandes Costa Instituto Camillo Filho

Rua Napoleão Lima, 1175, Jockey Club

64049-220, Teresina, PI, Brasil

Pedro Vilarinho Castelo Branco

Universidade Federal do Piauí

Campus Universitário Ministro Petrônio Portella

CCHL, Ininga

64049-550, Teresina, PI, Brasil 